Journal of Animal and Veterinary Advances 11 (2): 186-190, 2012

ISSN: $1680-5593$

(C) Medwell Journals, 2012

\title{
Evaluation of Fattening Performance of Holstein Cattle at Different Initial Weights Under Summer Season Conditions in the District of Silifke of Mersin Province
}

\author{
Durhasan Mundan, Salih Gogebakan, Cansu Ergun and I. Halil Kaban \\ Department of Animal Sciences, Faculty of Veterinary Medicine, \\ Harran University, Sanliurfa, Turkey
}

\begin{abstract}
This study was done in order to analyze the fattening performance of Holstein cattle which are under Summer season conditions in the district of Silifke of Mersin province. A total of 56 head Holstein cattle which are in commercial cattle fattening enterprise doing intensive production were fattened by dividing them into lighter (G-I) and heavier (G-II) according to weights of per feeding. Initial weight, average daily live weight gain, finishing weight, live weights gain and feed conversion rate for G-I and G-II were 99.03 \pm 2.32 and 205.27 \pm 5.15 , $1.081 \pm 0.04$ and $1.108 \pm 0.04 \mathrm{~g}, 293.68 \pm 5.74$ and $404.64 \pm 6.95$ and $194.65,199.37 \mathrm{~kg}$ and 6.8 and $7.1 \%$, respectively. The cattles were put into the enterprise in April, 2010. Both groups separated from the enterprise at the end of the 180 days fattening. Independent t-test was used in order to determine whether there was a differentiation between groups. Differences between groups in terms of initial weight and finishing weight were significant $(\mathrm{p}<0.001)$. Differences between the groups in terms of the average Daily Live Weight Gain (DLWG) and Feed Conversion Rate (FCR) were not significant statistically $(\mathrm{p}>0.01)$. As a result, it was found that initial weight in the daily live weight gain of Holstein cattle in Summer season conditions in the district of Silifke of Mersin province was not important also it was found that cattle were affected by the temperature and humidity, cattle fattening performance was subnormal and the performance could be increased by shower and fan application.
\end{abstract}

$\underline{\text { Key words: Fattening performance, daily live weight gain, Temperature Humidity Index (THI), holstein, Turkey }}$

\section{INTRODUCTION}

Fattening is a part of the business that contribute to the development and industrialization of the country by creating new employment. The vast majority of meat and milk consumption in developed country are obtained from the cattle. About $92 \%$ of milk and $77 \%$ of meat production were provided from the cattle in 2008 .

Fattening business owners in Turkey do not have enough (appropriate fattening material initial fattening age initial weight and optimum fattening period) basic information. Breeders generally do not care about the cattle they bought to be homogeneous in terms of live weight. Therefore, the live weight of bought cattle and fattened animals show a significant variation. The live weight gains and the feed consumption of these animals which are not homogeneous in terms of the live weight are also different. Having the information related to at what age and live weight of fattening cattle to start to fatten in Turkey in order to obtain the highest fattened performance from the cattle breeds by the business managements or guiding by the experts is absolutely necessary for the company to take profit in terms of economics (Koknaroglu et al., 2005, 2011). About 10, 723 and 958 head of cattle are grown in Turkey. Approximately 75.8 of these consist of culture species and hybrid. The cattle population is 11084 according to 2009 data in Silifke. Cattle breeding are common in areas where the bumps are less and there are meadows and pastures especially on Goksu valley settlements. The intensity of agriculture activities in Goksu valley increased cattle feeding but limited the hair goat breeding. In addition, many of the products cultivated on the plain are used as animal feed; cattle feeding are encouraged (Saribas and Pinar, 2009).

It is important for the race to be fattened in order to have a high level of milk as well as high fattened performance and quality meat production. Also, calves are preferred in the town berceuse they are portly in birth and they show a rapid growth. Turkey is on the border of subtropical climate zone, the South regions have a subtropical. Therefore, the Mediterranean region creates the stress factors for for animal breeding. Declining productivity is seen in the certain environmental conditions that situated over the threshold values. Threshold values which are determined by Temperature Humidity Index (THI) values in terms of

Corresponding Author: Durhasan Mundan, Department of Animal Sciences, Faculty of Veterinary Medicine, Harran University, Sanliurfa, Turkey 
Table 1: Some fattening performance in various genotype

\begin{tabular}{|c|c|c|c|c|c|c|}
\hline References & Genotypes & Initial weight $(\mathrm{kg})$ & Fattening period (days) & Finishing weight $(\mathrm{kg})$ & Average DLWG (g) & $\overline{\mathrm{FCR}(\%)}$ \\
\hline Akbulut and Tuzemen (1994) & $\mathrm{H}$ & 183.9 & - & 338.0 & 904.0 & 6.730 \\
\hline Akcan et al. (1989) & $\mathrm{H}$ & - & - & 400.0 & 1076.0 & - \\
\hline Akcan et al. (1991) & $\mathrm{H}$ & 231.0 & - & 435.0 & 1131.0 & 10.500 \\
\hline Akcan et al. (1992) & $\mathrm{S}$ & 148.7 & 270.0 & 435.7 & 1067.0 & 7.220 \\
\hline Alpan et al. (1976) & $\mathrm{H}$ & 130.0 & 180.0 & - & 1016.0 & 7.200 \\
\hline Altuntas and Arpacik (2004) & $\mathrm{S}$ & 118.0 & 364.0 & 504.8 & 1062.0 & 15.400 \\
\hline Arpacik et al. (1984) & $\mathrm{E}$ & 197.6 & 170.8 & 400.0 & - & - \\
\hline Arpacik et al. (1988) & $\mathrm{H}$ & - & - & 450.0 & 1080.0 & 7.400 \\
\hline Basaran and Akcan (1997) & $\mathrm{H}$ & 197.2 & 226.0 & 450.0 & 1133.0 & 7.086 \\
\hline Baspinar (1991) & $\mathrm{H} \times \mathrm{AB} \mathrm{F}_{1}$ & - & - & 500.0 & 865.8 & 8.570 \\
\hline Baspinar et al. (1999) & $\mathrm{H}$ & - & - & 550.0 & 1172.0 & 8.680 \\
\hline Ekizet al. (2005) & $\mathrm{BS}$ & 275.0 & 180.0 & 515.6 & 1336.0 & - \\
\hline Erkus et al. (1990) & $\mathrm{H}$ & 218.0 & - & 428.0 & - & - \\
\hline Gunes et al. (2001) & $\mathrm{H}$ & 355.3 & 138.0 & 473.3 & 860.0 & 9.900 \\
\hline Ilgu and Gunes (2002) & $\mathrm{H}$ & 311.1 & - & 464.8 & 1023.6 & 8.010 \\
\hline Koc and Akman (2003) & $\mathrm{H}$ & 246.4 & 237.8 & 476.0 & 964.3 & 7.970 \\
\hline Ozdogan (2007) & BS & 255.8 & 183.0 & 518.5 & 1440.0 & 6.400 \\
\hline Ozdogan (2007) & $\mathrm{H}$ & 258.0 & 183.0 & 502.4 & 1330.0 & 6.850 \\
\hline Ulutas et al. (1994) & EAR & - & 154.0 & - & 814.0 & 6.690 \\
\hline
\end{tabular}

AB: Anatolian Black breeds; BS: Brown Swiss; EAR: Eastern Anatolian Red; H: Holstein; S: Simmental; DLWG: Daily Live Weight Gain; FCR: Feed Conversion Rate

welfare are the subject for the cattle. Initial threshold value of stress for dairy cattle has been reported as $72 \mathrm{THI}$ and it has been reported as $84 \mathrm{THI}$ for fattening cattle (Armstrong, 1994). Welfare conditions for cattle are provided by applications such as shower and fan, etc., on these threshold values. Heat stress occurs on the cattle when the air temperature rises $>29^{\circ} \mathrm{C}$ (Morrison, 1983; Morrison and Prokop 1983; Mader et al., 1999). It is reported that the optimum conditions for fattening cattle are $10-15^{\circ} \mathrm{C}$ ambient temperature and $50-72 \%$ relative humidity.

A large number studies about fattening of cattle have been done in Turkey (Table 1). Fattening performance of local, hybrid and culture cattle were evaluated in several studies.

Live weight gain in fattening cattle varies according to climatic conditions. Fattening performance is affected negatively where the ambient temperature is higher. This study was done in order to analyze the fattening performance of Holstein cattle chosen from a commercial cattle fattening enterprise near the Mediterranean coast and which are under Summer season conditions in the district of Silifke of Mersin province.

\section{MATERIALS AND METHODS}

About 56 male Holstein cattle collected from the nearby villages and towns in April, 2010 and which were brought to enterprise at different age and live weight were used as research materials. The study was conducted between the months of April to October of 2010. About 56 head cattle brought to enterprise were divided into 2 groups as light (G-I) and heavy (G-II) according to weight per heeding and they were taken to different areas. An area of $5 \mathrm{~m}^{2}$ per cattle in GI and $7 \mathrm{~m}^{2}$ per cattle in G-II was allocated. Live weight of cattle per beef was specified when they were brought to the enterprise. Weight gains were recorded as once in a month until the end of fattening. The weighing was done in the morning before being feed and watered.

About 15 days weights of the cattle were determined by interpolation. Attention was paid to doing the live weight weighing of animals at the same time and not allowing the animals being in stress during the weighing. Cattle were got fattened on April 9, 2010 and they were kept in the barn until they completed fattening. They were excluded from the farm at the end of 180 days fattening, on October 6, 2010.

Medication against internal and external parasites was done to the cattle brought into the farm at the beginning of fattening and $\mathrm{A}, \mathrm{D}_{3}$ and vitamin $\mathrm{E}$ were injected every month. Any precautions such as shower and fan applications, etc., were not taken against the high temperatures in the farm. The following equation is used in the calculation of DLWG:

$$
\text { DLWG }(\mathrm{kg})=\frac{\text { Finishing weight }(\mathrm{kg})-\text { initial weight }(\mathrm{kg})}{\text { Fattening period (days) }}
$$

Fattening performance analysis was assessed by Minitab package program and t-test was done for independent samples. The food given during the fattening for cattle was recorded. Concentrated feed up to they consumed was given to the cattle and water needs were met from float water containers which were always accessible.

Chemical composition of the diets which were used for fattening in the farm are shown in Table 2. Feed conversion rates between the groups were calculated by 
dividing the total amount of food consumed between the weighing days to the total live weight gain of the groups:

$$
\mathrm{FCR}=\frac{\text { Feed consumed }(\mathrm{kg})}{\text { Gained live weight gain }(\mathrm{kg})}
$$

Temperature and humidity levels for each month are shown in Table 3. Temperature humidity index was calculated by the equation as follows (Clark, 1981):

Where:

$$
\mathrm{THI}=0.72 *(\mathrm{Ta}+\mathrm{Tdp})+0.46
$$

$\mathrm{THI}=$ Temperature humidity index

$\mathrm{Ta}=$ Thermometer arid $\left({ }^{\circ} \mathrm{C}\right)$

$\mathrm{Tdp}=$ Thermometer $\operatorname{damp}\left({ }^{\circ} \mathrm{C}\right)$

Table 2: Chemical composition of the diets

\begin{tabular}{lclc}
\hline Feed ingredients & Percentage & Nutrients & Percentage \\
Straw & 9.2 & Dry substance & 89.8000 \\
Sugar beet pulp & 55.0 & Raw protein & 12.1000 \\
Wheat fracture & 17.9 & Raw cellulose & 6.5800 \\
Sunflower meal & 7.2 & Raw fat & 2.7400 \\
Bran & 4.1 & Calcium & 0.4600 \\
Molasses & 5.3 & Phosphor & 0.0430 \\
Dicalcium phosphate & 0.7 & ME (kcal kg $\left.{ }^{-1} \mathrm{DM}\right)$ & 2601.9000 \\
Salt & 0.4 & - & - \\
Vitamin-mineral & 0.2 & - & - \\
Total & 100.0 & - & - \\
\hline
\end{tabular}

ME: Metabolic Energy; DM: Dry Matter

Table 3: Temperature and humidity levels for each month of 2010 in Mersin/Silifke

\begin{tabular}{lccccccc}
\hline Factors & April & May & June & July & August & September & October \\
\hline $\begin{array}{l}\text { Average } \\
\text { temperature }\left({ }^{\circ} \mathrm{C}\right)\end{array}$ & 18.3 & 21.5 & 25.1 & 27.7 & 30.0 & 27.2 & 22.4 \\
$\begin{array}{l}\text { Average } \\
\text { humidity (\%) }\end{array}$ & 49.1 & 60.5 & 52.4 & 59.9 & 53.7 & 46.8 & 44.3 \\
\begin{tabular}{l} 
THI \\
\hline
\end{tabular} & 65.0 & 68.0 & 73.0 & 78.0 & 79.0 & 75.0 & 68.0 \\
\hline
\end{tabular}

\section{RESULTS AND DISCUSSION}

Statistical values related to weights of fattening about various periods are shown in Table 4. Initial and finishing fattening live weights of cattle were calculated, respectively as $99.03 \pm 2.32$ and $205.27 \pm 5.15,293.68 \pm 5.74$ and $404.64 \pm 6.95 \mathrm{~kg}$ in G-I and G-II groups. Variation measurements remain at normal levels according to Table 4.

Statistical values of fattening performance in the groups are shown in Table 5. Differences between groups were significant in terms of initial fattening and finishing weight of cattle $(p<0.001)$. Statistical values related to DLWG of fattening in groups from various periods are shown in Table 6 . According to these values the highest DLWG of G-I is between 120-150th days and the highest DLWG of G-II is between 91-105th days. The average DLWG were similar in both groups.

DLWG of fattening cattle was calculated for each month and it is shown Fig. 1. The average DLWG of fattening cattle between April and September was calculated. Accordingly, the highest DLWG of G-I was in August and the highest DLWG of G-II was in July. DLWG was lower in other months.

The average air temperature in Summer ranged between $18.3-30.0^{\circ} \mathrm{C}$ in Mersin/Silifke, relative humidity values ranged from $44.3-60.5 \%$. In this study, it has been found that the initial weight is lower than the studies of Ilgu and Gunes (2002) and Koc and Akman (2003).

In this study, it has been found that fattening period is similar to the studies of Alpan, Arpacik, Ekiz and Ozdogan; it is lower than the studies of Koc and Akman (2003); it is higher than the studies of Arpacik, Ulutas and Gunes.

\begin{tabular}{|c|c|c|c|c|c|c|c|c|c|c|c|c|}
\hline \multirow[b]{2}{*}{ Days } & \multicolumn{6}{|c|}{ G-I } & \multicolumn{6}{|c|}{ G-II } \\
\hline & $\mathrm{n}$ & $\mathrm{X} \pm \mathrm{Sx}$ & $\mathrm{S}$ & Min. & Max. & $\mathrm{V}(\%)$ & $\mathrm{n}$ & $\mathrm{X} \pm \mathrm{Sx}$ & $\mathrm{S}$ & Min. & Max. & $\mathrm{V}(\%)$ \\
\hline Initial weight & 35 & $99.03 \pm 2.32$ & 13.74 & 68.0 & 125.0 & 13.9 & 41 & $205.27 \pm 5.15$ & 33.01 & 150.0 & 300.0 & 16.1 \\
\hline 15th & 35 & $111.57 \pm 2.55$ & 15.07 & 85.5 & 143.0 & 13.5 & 41 & $220.41 \pm 5.21$ & 33.34 & 163.2 & 318.2 & 15.1 \\
\hline 30th & 35 & $124.76 \pm 2.93$ & 17.33 & 97.6 & 163.0 & 13.9 & 41 & $236.48 \pm 5.36$ & 34.34 & 177.4 & 337.7 & 14.5 \\
\hline 45th & 35 & $139.47 \pm 3.17$ & 18.74 & 106.9 & 181.7 & 13.4 & 41 & $252.49 \pm 5.49$ & 35.15 & 191.5 & 358.1 & 13.9 \\
\hline 60th & 35 & $156.24 \pm 3.40$ & 20.08 & 118.0 & 201.1 & 12.9 & 41 & $268.57 \pm 5.70$ & 36.51 & 204.9 & 380.8 & 13.6 \\
\hline 75th & 35 & $172.13 \pm 3.61$ & 21.34 & 130.0 & 213.0 & 12.4 & 41 & $284.61 \pm 5.88$ & 37.64 & 215.0 & 399.5 & 13.2 \\
\hline 90th & 35 & $187.49 \pm 3.76$ & 22.21 & 143.7 & 229.7 & 11.8 & 41 & $301.62 \pm 5.95$ & 38.11 & 231.0 & 410.1 & 12.6 \\
\hline 105th & 35 & $204.17 \pm 3.96$ & 23.41 & 159.1 & 253.5 & 11.5 & 41 & $319.51 \pm 6.09$ & 38.99 & 247.3 & 421.7 & 12.2 \\
\hline 120th & 35 & $221.41 \pm 4.13$ & 24.43 & 171.5 & 277.2 & 11.0 & 41 & $336.64 \pm 6.24$ & 39.93 & 267.5 & 446.7 & 11.9 \\
\hline 150th & 35 & $258.25 \pm 4.64$ & 27.47 & 211.5 & 328.6 & 10.6 & 41 & $371.35 \pm 6.53$ & 41.79 & 304.0 & 488.7 & 11.3 \\
\hline 180th & 35 & $293.68 \pm 5.74$ & 33.96 & 239.9 & 401.5 & 11.6 & 41 & $404.64 \pm 6.95$ & 44.51 & 335.3 & 523.7 & 11.0 \\
\hline
\end{tabular}

Table 4: Statistical values related to weights of fattening from different periods in the groups $(\mathrm{kg})$

\begin{tabular}{|c|c|c|c|c|c|c|c|c|}
\hline Group & $\mathrm{n}$ & $\begin{array}{c}\text { Initial } \\
\text { weight }(\mathrm{kg})\end{array}$ & $\begin{array}{l}\text { Fattening } \\
\text { period (day) }\end{array}$ & $\begin{array}{l}\text { Average } \\
\text { DLWG (g) }\end{array}$ & $\begin{array}{l}\text { Live weights } \\
\text { gain (kg) }\end{array}$ & $\begin{array}{l}\text { Finishing } \\
\text { weight (kg) }\end{array}$ & FCR (\%) & $\begin{array}{c}\text { The area } \\
\text { per animal }\left(\mathrm{m}^{2}\right)\end{array}$ \\
\hline G-I & 35 & 99.03 & 180 & 1.081 & 194.65 & 293.68 & 6.8 & 5 \\
\hline G-II & 41 & 205.27 & 180 & 1.108 & 199.37 & 404.64 & 7.1 & 7 \\
\hline $\mathrm{p}$-value & 56 & 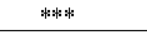 & NS & NS & NS & $* * * * *$ & NS & - \\
\hline
\end{tabular}

S: Standard deviation; V (\%): Variation (\%)

NS: Not Significant; ${ }^{* * * *} \mathrm{p}<0.001$ 
Table 6: Statistical values related to DLWG of fattening in groups from various periods (g)

\begin{tabular}{|c|c|c|c|c|c|c|c|c|c|c|}
\hline \multirow[b]{2}{*}{ Days } & \multicolumn{5}{|c|}{ G-I } & \multicolumn{5}{|c|}{ G-II } \\
\hline & $\mathrm{n}$ & $\mathrm{X} \pm \mathrm{Sx}$ & $\mathrm{S}$ & Min. & Max. & $\mathrm{n}$ & $\mathrm{X} \pm \mathrm{Sx}$ & $\mathrm{S}$ & Min. & Max. \\
\hline $1-15$ th & 35 & $0.836 \pm 0.05$ & 0.30 & 0.467 & 1.648 & 41 & $1.009 \pm 0.04$ & 0.26 & 0.482 & 1.493 \\
\hline 16-30th & 35 & $0.880 \pm 0.05$ & 0.28 & 0.517 & 1.516 & 41 & $1.072 \pm 0.04$ & 0.27 & 0.516 & 1.600 \\
\hline $31-45$ th & 35 & $0.981 \pm 0.04$ & 0.22 & 0.586 & 1.413 & 41 & $1.068 \pm 0.04$ & 0.23 & 0.660 & 1.486 \\
\hline 46-60th & 35 & $1.118 \pm 0.05$ & 0.30 & 0.672 & 1.966 & 41 & $1.072 \pm 0.04$ & 0.27 & 0.552 & 1.793 \\
\hline $61-75$ th & 35 & $1.060 \pm 0.04$ & 0.26 & 0.707 & 1.908 & 41 & $1.069 \pm 0.04$ & 0.25 & 0.623 & 1.784 \\
\hline $76-90$ th & 35 & $1.024 \pm 0.04$ & 0.23 & 0.633 & 1.794 & 41 & $1.134 \pm 0.03$ & 0.22 & 0.686 & 1.765 \\
\hline 91-105th & 35 & $1.111 \pm 0.04$ & 0.23 & 0.621 & 1.750 & 41 & $1.193 \pm 0.04$ & 0.28 & 0.517 & 1.729 \\
\hline 106-120th & 35 & $1.149 \pm 0.04$ & 0.24 & 0.700 & 1.700 & 41 & $1.142 \pm 0.05$ & 0.29 & 0.533 & 1.707 \\
\hline 121-150th & 35 & $1.228 \pm 0.05$ & 0.31 & 0.700 & 2.162 & 41 & $1.157 \pm 0.03$ & 0.21 & 0.618 & 1.669 \\
\hline 151-180th & 35 & $1.180 \pm 0.07$ & 0.44 & 0.600 & 2.967 & 41 & $1.110 \pm 0.03$ & 0.22 & 0.417 & 1.500 \\
\hline General & 35 & $1.081 \pm 0.04$ & 0.28 & 0.620 & 1.882 & 41 & $1.108 \pm 0.04$ & 0.25 & 0.560 & 1.653 \\
\hline
\end{tabular}

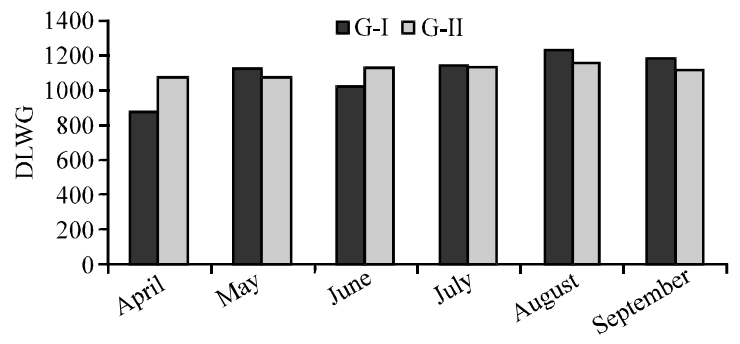

Fig. 1: The average DLWG of fattening cattle in different months

In this study, it has been found that finishing weight is similar to the studies of Akcan and Arpacik, it is lower than the studies of Ilgu and Gunes (2002), Koc and Akman (2003) and Ozdogan (2007); it is higher than the studies of Akbulut and Tuzemen. In this study, it has been found that the average DLWG is similar to the studies of Akcan, Alpan, Altuntas and Arpacik, Arpacik and Basaran; it is higher than the studies of Koc and Akman (2003) and Ulutas.

In this study, it has been found that live weight gain after fattening is similar to the studies of Akcan, Arpacik and Erkus; it is lower than the studies of Koc and Akman (2003) and Ozdogan (2007); it is higher than the studies of Ilgu and Gunes (2002). In this study, it has been found that FCR is similar to studies of Koc and Akman (2003) and Ozdogan (2007); it is lower than the studies of Ilgu and Gunes (2002) and Gunes.

Finishing weight of fattening being low from the other studies can be caused from temperature conditions of the region and being excluded from the farm after 180 days. Although, it has been found that initial and finishing weight of fattening between groups is significant $(p<0.001)$, it has been found that DLWG and live weight gain are not significant. It shows that whether the weight of the fattening is light or heavy is not important in the similarity between the groups. Although, the temperature humidity index for fattening cattle keeps within the limit of danger, the cattle have engaged in heat stress because it exceeds the threshold value between June and September.

\section{CONCLUSION}

This study is important for determining the fattening performance cattle which are in the commercial fattening enterprise which is near the edge of the sea in the district of Silifke of Mersin province and providing information about the region in terms of cattle fattening. It is concluded that the temperature and relative humidity range in the district of Silifke of Mersin province causes heat stress in cattle as a result of this it lowers the rate of feed efficiency by drinking more water. The resistance to cold conditions of Holstein cattle race is good. They do not show the same success in hot conditions. Cooling possibilities such as shower and fan are necessary in order to obtain the desired performance in the hot climate regions. Breeders living in hot and humid regions should prefer doing the fattening in cool periods and give break to fattening activities in the Summer. If it needs to be done in the Summer, they should use shower and fan in order to cool the cattle.

\section{REFERENCES}

Armstrong, D.V., 1994. Heat stress interaction with shade and cooling. J. Dairy Sci., 77: 2044-2050.

Clark, J.A., 1981. Environmental Aspects of Housing for Animal Production Butterworth-Heinemann Ltd., London, ISBN-13: 978-0408106887, Pages: 528.

Ilgu, E. and H. Gunes, 2002. Studies on the feedlot performance of male Holstein Friesian cattle under private farm conditions. J. Fac. Vet. Med. Univ., 28: 313-335.

Koc, A. and N. Akman, 2003. Fattening performance and carcass characteristics of imported Holstein bulls at different initial weight. J. Anim. Prod., 44: 26-36.

Koknaroglu, H., D.D. Loy, D.E. Wilson, M.P. Hoffman and J.D. Lawrence, 2005. Factors affecting beef cattle performance and profitability. Prof. Anim. Sci., 21: $286-296$. 
Koknaroglu, H., M.P. Hoffman, D.D. Loy, A. Trenkle and J.D. Lawrence, 2011. Integration of pasturing systems for cattle finishing programs. Asian J. Anim. Vet. Adv., 6: 132-154.

Mader, T.L., J.M. Dahlquist, G.L. Hahn and J.B. Gaughan, 1999. Shade and wind barrier effects on Summer time feedlot cattle performance. J. Anim. Sci., 77: 2065-2072.

Morrison, S.R. and M. Prokop, 1983. Beef cattle response to air temperature: Effect of body weight and ration composition. Trans. Am. Soc. Agric. Biol. Eng., 26: 893-894.
Morrison, S.R., 1983. Ruminant heat stress: Effect on production and means of alleviation. J. Anim. Sci., 57: 1594-1600.

Ozdogan, M., 2007. A research on some fattening performance parameters of Holstein Friesian and brown Swiss young bulls under Summer season conditions in Aydin province. J. Anim. Prod., 48: $1-6$.

Saribas, M. and A. Pinar, 2009. The effect of landforms and vegetation on the distrubituon of cattle, sheep and goat. Selcuk Univ. Social Sci. Inst., 22: 367-382. 